\title{
Moral origins and Christian ethics: An interdisciplinary approach in conversation with J. Wentzel van Huyssteen
}

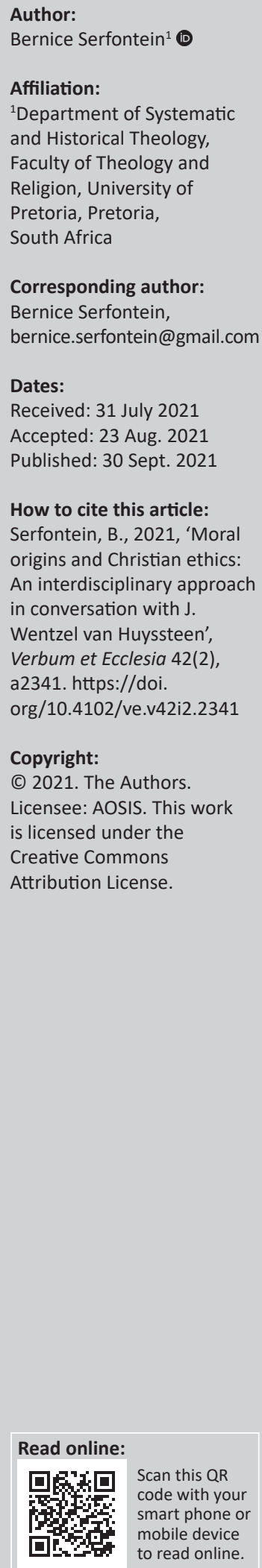

Only a small number of theologians attempt to explore the critical and constructive contributions theology can make to evolutionary accounts of morality. J. Wentzel van Huyssteen can be considered a pioneer in the science and theology discourse, with a special interest in the origin of morality as part of his pursuit of a more profound notion of human uniqueness in science and theology. In this article, the origin of moral awareness and morality will be explored by combining a variety of perspectives, including evolutionary anthropology, in an attempt to gain a more responsible notion of ethics and clarify its relationship to Christian theology. The interdisciplinary approach adopted in this study, in conversation with Van Huyssteen, reveals the necessity of distinguishing between moral awareness and morality, that is, moral norms, judgements and conventions. Evolutionary explanations of our innate sense of morality cannot explain any of our moral judgements or justify the truth claims regarding our moral judgements. Gaining insights from philosophy and developmental psychology, the origin of moral norms, judgements and conventions are explored on a more interactive level of cultural evolution and niche construction. Finally, this article briefly explores whether Van Huyssteen's post-foundational rethinking of the imago Dei can offer insights into how this bottom-up approach to moral awareness and morality relates to Christian theology and ethics.

Intradisciplinary and/or interdisciplinary implications: This article, in conversation with Wentzel van Huyssteen, explores the origin of moral awareness and morality and its relation to ethics. The interdisciplinary conversation covers the fields of evolutionary anthropology, developmental psychology, philosophy and theology within the contemporary science and theology discourses.

Keywords: moral awareness; morality; evolutionary anthropology; niche construction theory; ethics; Christian theology; philosophy; imago Dei; Wentzel van Huyssteen.

\section{Introduction}

I owe an enormous debt to Professor J. Wentzel van Huyssteen whose pioneering work in theology and science discourse has shaped my thinking in significant ways. Within his fascinating corpus of research in the interdisciplinary discourse between Science and Theology, I wish to focus on one component, how evolutionary theory can be usefully applied to interdisciplinary Christian theology and ethics. Almost all human life and every human society are pervaded with ethics. In line with Van Huyssteen, I would like to argue that a responsible notion of ethics is based on a credible understanding of human personhood, that is, what it means to be human. The origin of moral awareness and morality has long been viewed exclusively from a 'top-down' perspective. Such a perspective is largely based on the assumption that morality and religion are somehow synonymous. This essay agrees with Van Huyssteen, and other leading scholars in the field, that the ability for moral awareness has biological roots and is, therefore, innate to the human species. Rather than descending on to us, top-down, from some external source or religious deity, moral awareness, in this view, emerges bottom-up from our capacity for empathy, our dayto-day social interactions and cooperation, which evolved during our hominin history. Exploring the origin of the human capacity for moral awareness employing evolutionary theories, might bring us closer to a more responsible notion of ethics and more specifically Christian Ethics.

As Van Huyssteen (2006:8) rightly states, Theology and the Sciences find a shared research trajectory on the topic of Human Uniqueness. For him (Van Huyssteen 2006:8) the most crucial aspect of his interdisciplinary dialogue with the sciences on Human uniqueness was to construct transversal connections with those sciences that focus directly on human origins, that is,

Note: Special Collection: Wentzel van Huyssteen. 
Palaeoanthropology and Archaeology. Calcagno and Fuentes (2012:194) confirm that an interdisciplinary exploration that includes an evolutionary perspective is most definitely required in answering important questions on what it means to be human. One common way of specifying human distinctiveness, according to Van Huyssteen (2016:1), is to make an explicit distinction between anatomical and behavioural differences. Anthropologist Agustín Fuentes (2009:3) agreed and emphasised the importance of distinguishable behaviour in this quest: 'Behaviour matters. It is what humans do. We have self-awareness, a cognitive complexity and an ability to reflect on ourselves, which is not available to other animals'. An evolutionary perspective on the question of being human reveals that language, selfawareness, moral awareness, imagination and consciousness are some of the characteristics that make humans distinct from other species (Van Huyssteen 2017a:8). These characteristics are often the least visible in prehistoric records. By bringing Frans de Waal (primatologist) and Michael Tomasello (professor in Psychology and Neuroscience) in conversation with Van Huyssteen and other prominent voices in the discourse, I would like to explore the origin of one such uniquely human aspect - moral awareness - in an attempt to determine how it might bring us closer to a more responsible notion of ethics.

Van Huyssteen (2017b:3) further makes us aware of the important distinction between the origin of moral awareness and the origin of morality, that is, moral norms and judgements. Against the background of niche construction theory, it becomes clear that evolution by natural selection and genetics do indeed play an important role in the human species' innate sense of moral awareness, that is, the human inclination to think in normative terms. However, biological evolutionary explanations of this moral awareness are unable to explain moral judgements. The question of how and why human beings make moral judgements can only be explained on a more complex level of niche construction, which includes cultural evolution. The historical embeddedness of human moral codes in political and religious conventions should also be taken into consideration. We might find surprising answers to the question of how and why we make moral judgements within the perspective of human ontogeny and cultural evolution. In the second part of this essay, I am going to explore the evolution of morality against the background of an analysis of Michael Tomassello's fascinating work on human ontogeny in conversation with Philip Kitcher. Lastly, I would like to ask how all this relates to ethics and specifically Christian Ethics.

Contemporary accounts of the evolution of human morality mainly fit into one of three very broad categories: 'evolutionary ethics, moral psychology and gene-culture coevolution' (Tomasello 2016:137). The accounts clustered under the general heading of evolutionary ethics concentrate on theoretical principles of cooperation in evolution and how they might apply to human beings. The groundwork from this view is most probably The Biology of Moral Systems
(Alexander 1987), which stresses processes of reciprocity, and especially, indirect reciprocity, in human beings. Sober and Wilson (1998) and De Waal (1996) also argued for the importance of reciprocity, in addition they emphasise empathy and sympathy as foundational to human cooperation and morality. Kitcher (2011) highlighted the role of altruism in human evolution but argues that altruism could not underpin proper human morality except if some other aspect such as 'normative guidance' also developed to nurture evolving individuals into the normative standards of a certain group. The more recent theories of Boehm (2012) and Baumard, André \& Sperber (2013), respectively, emphasise the role of social selection and specifically partner choice. Almost all scholars in this broad category of evolutionary ethics agree that sympathy and empathy play an important part in the origin of morality. But, as Tomasello (2016:138) observed, the tendency is to try to cover everything else with one or another form of reciprocity. The view of Tomasello (2016), however, is that reciprocity is limited as an explanatory framework and that the notion of interdependence which can also be viewed as several kinds of symbiosis - is much more comprehensive. Van Huyssteen (2017b:6) regards evolutionary ethics, as the understanding that morality has evolved and there are distinguishable pointers to the biological roots of moral behaviour in hominin history. About the biological roots of moral awareness and morality, Van Huyssteen (2006, 2017a:4, cf. Fuentes 2014) emphasised the necessity to identify interdisciplinary points of connection over explanatory frameworks whose focus is not limited to just one specific set of explanations of the moral sense and morality. In the brief exploration of the construction of the uniquely human niche that follows, it becomes evident that the human imagination is one such interdisciplinary point of connection that becomes part of the explanation of the origin of moral awareness.

\section{Constructing the human niche}

A once rather basic story of humanity has been transformed by recent discoveries and theoretical shifts in evolutionary theory and biology. It became increasingly clear that the genes of the human species reveal only one aspect of how humans became successful in the face of increasing levels of complexity (Fuentes 2017:5). There is indeed much more to evolution than merely the inheritance of genes. According to Van Huyssteen (2017a:4), it is essential to obtain an interactive perspective on evolution, which dismisses any explicit prioritisation in inheritance systems and consequently requires a purposeful divergence from methods that are limited to either biological or social focuses. This theory views evolution as a process of 'construction' and argues that evolution is never a mere matter of a biologically developing organism. Rather, as Van Huyssteen (2017a:4) stated, evolution is a matter of organism and environment systems changing gradually over time in an interactive and dynamic niche construction process. Laland et al. (2015:4) defined niche construction as the process through which the metabolism, activities and choices of organisms modify or stabilise environmental states, and in this manner, affect 
selection acting on themselves and other species. In the process of niche construction, an organism responds to the challenges and conflicts of the environment through reshaping the very pressures the world placed on it (Fuentes 2017:10). In essence, the niche is an amalgamation of the ecology in which an organism exists and the way it makes a living.

The distinctive evolutionary history of Homo sapiens sapiens ${ }^{1}$ gives insight into how much we have in common with our evolutionary counterparts and also provides us with answers to the question of what happened in the human genus during the last 2 million years. An exploration of the evolution of modern humans should explain the development of bodies and the species' unique modification to ecologies. It is therefore, necessary to develop a model that encompasses all critical interlocking systems of the human niche.

Following the insights of many scholars (Antón, Potts \& Aiello 2014; Foley 2016; Fuentes 2020; Gamble, Gowlett \& Dunbar 2011) we can argue that the human lineage underwent significant morphological changes along with notable behavioural and cognitive modifications as it forged and was shaped by new niches. However, behavioural and cognitive modifications are not so easily measurable. The emergence of the uniquely human niche is evident across the Pleistocene. In the most basic understanding, a niche consists of space, structure, climate, nutrients and other physical and social factors as they are experienced and restructured through organisms and the presence of collaborators, competitors and other agents in a shared environment (Wake, Hadley \& Ackerly 2009:19631-19636; see also Fuentes 2016:14). Human niches are the context for the lived experience of humans and their communities. It is in their unique niche where 'kinship' and social and ecological histories are shared and where humans create and partake in shared knowledge, structural and social security and development across the lifespan (Fuentes 2020:18). Consequently, ideologies, institutions and cultural practices also form part of human niches. In a nutshell, during the Pleistocene, the human lineage developed a distinctive set of neurological, physiological and social skills that enabled us to think together and work together to create and collaborate at cumulative levels of complexity. This collaboration intrinsically involves a capacity for imagination, the intensification of the use of signs and the creation and use of symbol (Fuentes 2020:21).

Ontogeny is also influenced by niche construction, which constitutes an important way in which environmental factors are incorporated into normal development (Laland et al. 2015:4). Ontogeny shapes individuals by constructing an intricate and interrelated set of ontogenetic pathways. Tomasello (2019:22) pointed to the notion that in modern evolutionary developmental biology (Evo-Devo), the goal of

\footnotetext{
1.Homo sapiens sapiens, or modern man, is a sub species of $H$. sapiens sapiens and emerged about $40000-130000$ years ago. According to Van Huyssteen (2017c:171; see also Fuentes 2017) the difference is apparent in the final transition from becoming Human ( $H$. sapiens) to being Human ( $H$. sapiens sapiens). The term $H$. sapiens refers to 'early humans', which emerged about 400000 years ago. The term H. sapiens sapiens is sometimes foreign to readers and therefore in this article, I will mainly use the 'modern humans' when referring to $H$. sapiens sapiens.
}

natural selection is not merely adult 'traits', as classical accounts reveal but rather ontogenetic pathways. This means that natural selection is not only essential for adult 'endpoints' but also for the construction process that establishes them (Gould 1977; West-Eberhard 2003). Ontogenetic pathways may change over evolutionary time, which results in different species, living in different ecological conditions, evolving different patterns of ontogenetic construction or life-history strategies (Tomasello 2019:23). This modern evolutionary developmental biology perspective on ontogeny is an epigenetic perspective which, as Tomasello (2019:23) explained is: 'focused not on genes but gene expression as it manifests in ontogenetic processes transacting with environments and with one another to create phenotypes'. It is clear that a more in-depth evolutionary approach to human personhood, which includes human psychological development, will describe and explain the dynamic processes that construct particular ontogenetic pathways. Against this background Tomasello (2019:22) argues that human ontogeny unfolds within a highly cooperative social group (culture), whose members collaborate and help one another in myriad ways. Humans constructed an especially cooperative ontogenetic niche. Against this perspective of niche construction theory, I would like to explore the origin of moral awareness and consequently ask how a bottom-up account of this moral awareness might lead to a bottom-up account of morality and ethics.

\section{Moral awareness and the human niche}

In her discussion on the origin of moral awareness, theologian (Deanne-Drummond et al. 2016) agrees with Van Huyssteen (2017b) that profound answers to the question of the origin of moral awareness can be found within the context of the unique human niche. The mere realisation that human moral - and religious - life did not develop separate from other animal species emphasises the importance of a niche construction perspective on the evolution of moral awareness (Deane-Drummond 2017:216). As is evident in the short overview of niche construction and human evolution, it is clear that during the unfolding of human evolution, modern humans have developed a unique niche in which imagination and symbol became vital factors of human ecology. Crucial to our capacity for symbolic behaviour is our capacity for imagination. From a theological and philosophical perspective, Van Huyssteen (2017a:4) argued, it is precisely here where the evolution of moral awareness and morality becomes crucially important. Van Huyssteen (2017a:4) emphasised the significance of studying the central role of the evolutionary transition between becoming and being human in any attempt to understand essential human traits such as moral awareness. The distinctively human imagination is a key part of the human niche and explanation for the evolutionary achievement of being human (Fuentes 2014:248).

By the late Pleistocene, genus homo confronted countless social and ecological challenges. The ability to utilise behavioural and cognitive processes that included a sense of 
imagination increased the likelihood of innovation in an attempt to successfully respond to the myriad challenges they were facing within their complex niche (Fuentes 2014:248). It is within this latter part of the Pleistocene that the first material evidence of imagination - primitive tool manufacturing - can be detected. According to Fuentes (2017:64) the manufacturing of tools, around 500000 years ago, required foresight, nuanced communication, some amount of teaching and a high level of manual dexterity. It also set in motion processes that provided possibilities of change and consequently groups of early humans gradually became smarter and more capable of imagining outcomes (Fuentes 2017:68). More complex forms of cooperation also required individuals to employ their ability for imagination to evaluate their actions, with regard to other individuals and the greater group (Tomasello 2019:19). It can, therefore, be argued that the substantial ecological challenges within the human niche generated greater complexity in cooperation and collaboration capacities, which required the capacity for imagination and which in turn facilitated the emergence of moral awareness and the various forms of morality known in modern humans.

In a captivating bottom-up perspective on the origin of moral awareness, De Waal (2013:298), emphasised the importance of bearing in mind that human bodies, minds and behaviour started simple. De Waal (2013:289) maintained that the key requirements or 'building blocks' for morality are reciprocity and empathy. Empathy, according to De Waal (2006:25), can be detected in primate behaviour and is a basic requirement in all social living. De Waal (2013:131) further argued that empathy connects bodies with bodies and is directly linked to the concept of emotional contagion - a process that involves imagination, analysis and conscious reasoning. From a philosophical perspective, Ricoeur (1992) developed a quite similar view of the human self in his publication Oneself as Another in which the self only becomes a true self through others, utilising empathy. An enlarged mentality capable of imagining the self in the place of the 'other' is required in this process. This process of awareness becoming selfawareness in the face of the 'other' entails a whole array of reciprocal and morally loaded relations. ${ }^{2}$

According to De Waal (2013:297) human beings can be differentiated from other non-human animals on a group level. Modern humans are deeply aware of the overall wellbeing of the group, consequently particular normative regulations were established to benefit the group. It is at this point that once again our very capacity for imagination plays an important part as it enables individuals to assess the impact of specific behaviour on the group. De Waal (2013:172) developed a bottom-up account of moral awareness consisting of two basic levels. The first level regards social relationships and is labelled one-on-one normativity, which reflects comprehension of how one's behaviour affects another individual. A second level, unique to humans, is that relation to moral awareness and ethics, see Serfontein (2018). of community concern. Personal interests are not denied on this level, but the aim is to acquire harmony within the larger community (De Waal 2013:222). Although several animals display rudimentary forms of community concern, it is here that human moral awareness diverges from anything encountered thus far.

Tomasello (2016:2), from a quite different angle, also emphasised that the complex interaction of the cooperation on group level gave rise to a unique form of moral awareness in early humans. He distinguishes between morality of sympathy, as a most elemental concern for the well-being of another, and morality of fairness that is more complex and most probably confined to the human species. Circumstances demanding fairness typically involves a compound interplay of the competitive and cooperative motives of multiple individuals. In general, Tomasello (2016:2) explained, whereas sympathy can be considered as pure cooperation, 'fairness is a kind of cooperativization of competition in which individuals seek balanced solutions to the many conflicting demands of multiple participants' various motives'. Grounded in substantial experimental data comparing human children and great apes, Tomasello $(2016,2019)$ reconstructed how Homo sapiens slowly became ultra-cooperative and, ultimately, a moral species. The core thesis of Tomasello's (2016) account of the natural history of moral awareness is that mutualistic cooperation, in which all parties involved benefit, created the foundation for the evolution of proximate psychological mechanisms that in due course formed the building blocks of human morality.

Tomasello et al. (2012:673-690) developed the interdependence hypothesis in which they provide a description of the evolution of uniquely human cooperation, starting with great apes, that concentrates on how early human individuals became all the more interdependent with one another in acts of cooperation. Most contemporary theories of the evolution of human cooperation are mainly focused on altruism. Alternatively, Tomasello et al. (2012:673) proposed that the species-unique forms of cooperation evident in human beings originate from mutualistic collaboration with social selection against cheaters. Ultimately two socio-ecological changes, resulted in $H$. sapiens being interdependent and gave rise to the evolution of initially joint and later collective intentionality (Tomasello 2016:3; Tomasello et al. 2012:674).

The first socio-ecological change about 400000 years ago scarcity of individually attainable resources - forced early humans to become obligatory collaborative foragers in such a way that individuals were interdependent with one another and consequently had an immediate interest in the welfare of their partners. This novel form of interdependence required early humans to now extend their sense of sympathy to collaborative partners and not just kin and friends (Tomasello 2016:4). Tomasello et al. (2012:673) explained that in this context early humans developed new capacities and motivations for collaboration not possessed by other great apes, that is, joint intentionality. The second evolutionary step and reaction to the second socio-ecological change - a 
sharp increase in population and changing demographics began with the emergence of $H$. sapiens sapiens about 150000 years ago. Modern human groups grew larger and consequently, they faced competition from other groups, which resulted in collaborative capacities and motivations that extended to group life in general (Tomasello 2016:5). Tomasello's (2016:3-4) fundamental argument for a natural history of morality is that the capacities and motivations to construct an interdependent, plural agent 'we' with others, that is, the capacities and motivations to participate with others in acts of shared intentionality, drove the human species from strategic cooperation to genuine morality. For Fuentes (2017:2) the distinctively human capacity for shared intentionality combined with imagination is how $H$. sapiens sapiens became who they are today.

It is clear that a bottom-up account of moral awareness can explain the tendency to think in normative terms, that is, the innate sense of moral awareness. However, such an account cannot explain moral judgements, norms or conventions. In what follows I will explore why and how we make moral judgements and create moral norms in an attempt to provide a bottom-up account of morality and ethics.

\section{Morality in the human niche}

Kitcher (2011:5) developed an interesting account for socially embedded normative guidance as a response to the limitations of psychological altruism. Kitcher (2011) referred to the development from an innate moral awareness to moral norms and ethical principles as the 'ethical project', which our ancestors started tens of thousands of years ago. Hominid ancestors were equipped with a capacity for psychological altruism and sympathy. However, the limitations of their altruistic dispositions challenged living together in small groups. They began overcoming these challenges by agreeing on certain rules of conduct to remedy some of the recurrent altruism failures that constraint their group life (Kitcher 2011:6). Most probably these early principles dealt with the sharing of resources and preventing violence. The normative ventures of our hominid ancestors led to the emergence of some principles we as modern humans are not likely to abandon should we strive to make ethical progress. These principles can be characterised as rather vague generalisations that represent ethical truths in our societies today. We have also inherited a sense of the ultimate good, which often includes not only conflicting elements but also provides us with, as Kitcher (2011:409) argued, 'a far richer conception of human life than any of the first ethical pioneers could have apprehended'.

From the perspective of human ontogeny, Tomasello (2016, 2019) also highlighted the role of establishing certain agreedupon principles required for healthy group dynamics as part of the development of moral norms and conventions. However, he does not view this development as a remedy to altruistic or sympathetic failure, but rather as an outcome of partner evaluation and selection necessary for interdependent cooperation. In many primate species, individuals evaluate each other for their suitability as social partners. More or less 400000 years ago, as early humans began moving towards a more cooperative interdependent lifestyle, as an essential part of obligate collaborative foraging, the evaluation process intensified. To survive and thrive it was necessary for early human individuals to select good collaborative partners and, crucially, to be selected by others as good collaborative partners themselves (Tomasello 2019:275). Individuals who were cognitively incapable of forming a joint goal or otherwise incompetent at collaborating were not repeatedly selected as partners, which resulted in fewer resources for them. Socially or morally uncooperative individuals - for example, those who did not want to share resources fairly were also not selected as regular partners. The outcome was a strong and active social selection for cooperatively competent and motivated individuals (Tomasello 2019:15; see also West-Eberhard 1979).

At this point, a completely new psychological process of joint intentionality based on joint agency emerged. Tomasello (2019:15) explained that a joint agent includes two individuals with a joint goal, planned through joint attention, whilst each individual has their role and perspective. A two-level structure emerged that involves both simultaneous sharing and individuality. Partners in joint agency interact dyadically and second-personally with one another in face-to-face relations. In due course, they form shared experiences and a mutual understanding on which their collaborative efforts may rely.

Early humans began to comprehend how the process of partner evaluation and selection worked, especially how it involved other individuals also evaluating and choosing them. This change in the evaluation process is unique to genus homo. According to Tomasello (2019:275), it became crucial for individuals to actively manage the impression they were making on others and to present to others in the group an identity as an individual who was cooperatively competent and trustworthy. Individuals were being judged and also judged others by the shared standards in the group and therefore they came to evaluate themselves in the same way they evaluated others. This process resulted in an internalised moral identity and so a species emerged that 'executively self-regulated its own beliefs and actions normatively - that is, morally' (Tomasello 2019:275).

Around 150000 years ago modern humans (H. sapiens sapiens) faced competition with other human groups and an increase in population size, which drove them to split into smaller groups. Some sort of tribal organisation followed in which several different social groups formed a single super-group or 'culture'. Recognising others from one's cultural group, as well as being recognised by others in one's group became essential. The dependence of individuals on the group generated some sense of group identity and loyalty. Consequently, modern humans' inclination towards dynamic conformity to the group and its conventional cultural 
practices emerged (Tomasello 2019:19). Modern human cultural groups entered into a variety of new ecological niches, and thus each group shaped its own distinct set of conventionalised cultural norms, practices and institutions altered for local conditions (Tomasello 2016:121). Instructing one's offspring to act according to the conventional way became unavoidable for their survival. Conformity and instruction gave rise to cumulative cultural evolution characterised by the 'ratchet effect' ${ }^{\prime 3}$ - and thus cultural organisation according to the group's distinct set of conventions, norms and institutions (Tomasello 2019:19). A kind of group-mindedness, in caring about the group's welfare and in cognitively taking the group's perspective, was the main characteristic of individuals successfully adapted for cultural life.

Certain social norms were mainly with reference to conformity and group identity whilst others involved humans' sense of sympathy and fairness - inherited from early humans - and these developed into moral norms (Tomasello 2019:20). Just as conventional norms specified the right and wrong means of acting in contributory activities, moral norms specified the right and wrong means of treating other individuals morally. Modern human morality was eventually characterised as objectively right and wrong because of the culture common ground and collective intentionality of modern humans that shaped a sort of 'objective' perspective on things. As part of the group identity the cultural norms into which modern humans were born were accepted as legitimate means by which 'we' regulate 'us'. Modern humans, therefore, created a reason-based moral identity within the moral community by internalising both moral actions and justifications (Tomasello 2019:21).

It becomes clear that modern humans self-regulated their actions and thoughts according to the normative standards of the group and not just according to what they imagined other individuals to be thinking of them - as early humans did. Modern humans started to self-regulate their behaviour based on the group's openly accepted norms of morality and their thoughts based on the group's openly accepted norms of rationality. As Tomasello (2019:21) puts it, modern humans 'observed not just social self-regulation but normative selfgovernance. They asked themselves, what ought I to think? And what ought I to do?'

Cultural group selection became another important part of the process, in which those cultural groups with the most effective and cooperative norms, conventions and institutions eliminated or assimilated other competing groups (Tomasello 2016:129). Especially important in this process was the domestication of various animal and plant species beginning around 12000 years ago. With the rise of agriculture and the cities it brought about people with very different cultural practices who came to live near one another. Innovative supra-individual regulatory devices were essential to creating cooperative arrangements in these new social circumstances. Tomasello (2016:129) stated that the most important regulatory devices, from the perspective of modern human morality, were law and organised religion.

This short interdisciplinary exploration of the origin of morality, that is, moral norms and judgements reveal how it is often mistakenly assumed that some high authority is required for ethics, some stance from which a particular truth can be accurately perceived. Both Kitcher and Tomasello provided a bottom-up account for moral norms and conventions and consequently ethics that are deeply rooted in our biological make-up. I would like to argue with Kitcher (2011:207) that in this perspective, ethics might merely be something we work out together. For Kitcher (2011:207) neither religion nor philosophy or any other single discipline can proclaim any authority over ethics. Eventually, the only authority is that of the ongoing transdisciplinary conversation.

\section{Towards a bottom-up view of Christian ethics}

Following the origin of moral awareness and morality from a niche construction perspective it becomes clear that around 100000 years ago, by the time they began their dispersion out of Africa in significant numbers, modern humans were moral in three ways. Firstly, modern humans had a morality of sympathy - a special sympathy for kin, cooperative partners, friends, paired with a sense of loyalty to their cultural compatriots. Secondly, they had a second personal morality of fairness - a sense of responsibility to act respectfully in their direct, twofold interactions with deserving others, which motivated them to treat those others fairly. Thirdly, modern humans had a group-minded cultural morality of justice (Tomasello 2016:129) - they felt an obligation for both the group and themselves to conform and to see to it that others conformed, to the fairly formulated norms, conventions and institutions of their cultural group, specifically those associated with second-personal morality.

In this perspective, a bottom-up view of moral awareness emphasises the notion that the moral sense is indeed an innate, evolved faculty. Evolutionary explanations of our moral awareness can, however, not explain moral judgement or justify any truth claims regarding our moral judgements. It becomes clear that in the case of Christian theology and ethics, there is no moral vision that is embedded in revelation and consequently 'received'. On a post-foundationalist view, Van Huyssteen (2017b:3) argued, 'our moral codes and ethical convictions of what is "received" is itself an interpretative enterprise shaped experientially through our embeddedness in complex niches of communities and cultures'. Even though religion is not the source for our capacity for morality, religion through history has played and still plays a profound role in how and why we make certain moral judgements. 
Moral codes are undeniably part of the core components of religions and particularly the Christian tradition. For Christian theology, the question of why we should be morally good is directly related to the question of why the personhood of Jesus might contain a moral imperative for Christian believers. In a fascinating reinterpretation of the theological symbol of the imago Dei, Van Huyssteen (2006:111-162) invited us to explore the notion that the complexity of human personhood in its evolutionary, biological, moral and social dimensions is an expression of the imago Dei. With his postfoundationalist approach to the question of human uniqueness in theology, specifically, as it relates to the notion of imago Dei in theology, Van Huyssteen (2006:160) came to the conclusion that the most comprehensive definition of the biblical concept of the imago Dei is embedded in one crucial text, Genesis 3:22a: 'Then the Lord God said, "See, the human being has become like one of us, knowing good and evil..."' For Van Huyssteen (2006:160) then, the most profound meaning of the concept of the image of God lies here, in the emergence of an embodied moral awareness, and a holistic, new way of knowing. An imaginative, embodied interpretation of the imago Dei reveals that the human capacity for religious meaning is deeply embedded in the human species' imaginative and symbolic behaviour. This perspective thus implies that the embodied human person has biologically evolved in history as a centre of selfawareness, religious awareness and moral responsibility (Van Huyssteen 2006:161). Such a rethinking of the imago Dei implies a liberating ethic of interpersonal relationships and ecological responsibility and becomes a source of direction that can guide human behaviour. The symbol of imago Dei gives rise to a notion of justice and fairness and represents a source metaphor for comprehending the human person. There is thus a strong ethical core to the theological concept of the imago Dei.

If one's faith is based on the conviction that the character and nature of God are revealed in the person of Jesus - the embodied consciousness, moral awareness, etc. of Jesus then it can be argued that there might be evolutionary and theological explanations why the words and deeds of Jesus are normative for us today as our moral codes and ethical norms are constructed. For Van Huyssteen (2006:274) the image of God is not found in humans, rather it is the human, and therefore it should be read as imitation Dei: to act like God. Following this line of thought one can argue that if the purpose of human beings, as created in the image of God, is as Van Huyssteen argued (2006:274) to set forth the presence of God in this word, it implies to set forth the embodied moral identity, as seen in the person of Jesus.

However, as Van Huyssteen (2010:152) made us aware, no sole interpretation of Jesus can be claimed to be final knowledge of God, as the revelation of God offered in Jesus is profoundly incarnational - embodied in the person of Jesus and embedded in the history of Jesus. No perception of God can be untouched by hermeneutical, epistemic and pragmatic obscurities of history. In a post-foundationalist perspective, learning what it means to follow the embodied moral identity of Jesus is to learn to discover the course on which others predated us in interpretation by embodying what we interpretatively distinguish as normative for our contemporary contexts. For Van Huyssteen (2010:157) then, relating Christology to ethics, in other words Christian Ethics is an unending interpretative task that can inspire us with moral direction even as it fills us with epistemic humility.

The interdisciplinary approach to moral origins and Christian ethics, in conversation with Van Huyssteen, yields the conclusion that interdisciplinary theology is able to responsibly reconceptualise Christian ethics. The key distinction between an inherent moral awareness and the evaluative discernment necessary for applying intelligent moral judgement does not, as Van Huyssteen (2017b:10) puts it, have to result in moral scepticism or relativism. Conversely, all of our beliefs do indeed have a very complex causal history. However, it would be impossible to determine from evolutionary, neurological capacities and broader cultural or philosophical motives behind the history of our belief systems that all of our beliefs are unfounded, as well as our moral norms and convictions. Yet following the interdisciplinary perspective adopted in this study, we should take seriously the notion that some of our religious beliefs, strong moral convictions and tendencies to moralise are indeed more credible and plausible than others. Recognising, then, that human moral awareness has evolved also implies recognising that human moral codes are not necessarily fixed and unchangeable entities. This resonates with Kitcher's (2011) notion of the 'ethical project', which is never complete as ethics - I would like to add Christian ethics - requires continuing efforts to discern how to live together in a common world. I am of the opinion that this perspective should encourage theologians to accept the responsibility to at least continue to explore what theology can and should contribute in any conversation on the origin of morality and ethics.

\section{Acknowledgements Competing interests}

The author declares that she has no financial or personal relationships that may have inappropriately influenced her in writing this article.

\section{Author's contributions}

B.S. is the sole author of this research article.

\section{Ethical considerations}

This article followed all ethical standards for research without direct contact with human or animal subjects.

\section{Funding information}

This research received no specific grant from any funding agency in the public, commercial or not-for-profit sectors. 


\section{Data availability}

Data sharing is not applicable to this article as no new data were created or analysed in this study.

\section{Disclaimer}

The views and opinions expressed in this article are those of the author and do not necessarily reflect the official policy or position of any affiliated agency of the author.

\section{References}

Alexander, R.D., 1987, The biology of moral systems, Aldine De Gruyter, New York, NY.

Antón, S., Potts, R. \& Aiello, L., 2014, 'Evolution of early homo: An integrated biological perspective', Science 345(6192), 1236828. https://doi.org/10.1126/ science.1236828

Baumard, N., André, J.B. \& Sperber, D., 2013, 'A mutualistic approach to morality', Behavioral and Brain Sciences 36(1), 59-122. https://doi.org/10.1017/S01405 25X11002202

Boehm, C., 2012, Moral origins: The evolution of virtue, altruism, and shame, Basic Books, New York, NY.

Calcagno, J.M. \& Fuentes, A., 2012, 'What makes us human? Answers from evolutionary anthropology', Evolutionary Anthropology 21(5), 182-194. https:// evolutionary anthropology',
doi.org/10.1002/evan.21328

Deane-Drummond, C., 2017, 'Empathy and the evolution of compassion: From deep history to infused virtue', Zygon 52(1), 258-278. https://doi.org/10.1111/zygo.12317

Deane-Drummond, C., Arner, N. \& Fuentes, A., 2016, 'The evolution of morality: A three dimensional map', Philosophy, Theology and the Sciences 3(2), 115-151. https://doi.org/10.1628/219597716X14696202742055

De Waal, F.B.M., 1996, Good natured: The origins of right and wrong in humans and other animals, Harvard University Press, Cambridge, MA.

De Waal, F.B.M., 2006, 'Morally evolved: Primate social instincts, human morality, and the rise and fall of "Veneer theory", in S. Macedo \& J. Ober (eds.), Primates and philosophers: How morality evolved, pp. 1-75, Princeton Science Library, Princeton University Press, Princeton, NJ.

De Waal, F.B.M., 2013, The bonobo and the atheist: In search of humanism among the primates, Norton, New York, NY.

Foley, R.A., 2016, 'Mosaic evolution and the pattern of transitions in the Hominin lineage', Philosophical Transactions of the Royal Society B: Biological Sciences 371(1698), 20150244. https://doi.org/10.1098/rstb.2015.0244

Fuentes, A., 2009, Evolution of human behaviour, Oxford University Press, Oxford.

Fuentes, A., 2014, 'Human evolution, niche complexity, and the emergence of a distinctly human imagination', Time and Mind 7(3), 241-257. https://doi.org/10.1 080/1751696X.2014.945720

Fuentes, A., 2016, 'The extended evolutionary synthesis, ethnography, and the human niche: Toward an integrated anthropology', Current Anthropology 57(S13), 13-26. https://doi.org/10.1086/685684

Fuentes, A., 2017, The creative spark: How imagination made humans exceptional, Penguin Random House LCC, New York, NY.
Fuentes, A., 2020, 'Setting the stage developing the human niche across the Pleistocene', in C. Deanne Drummond \& A. Fuentes (eds.). Theology and evolutionary anthropology: Dialogues in wisdom, humility and grace, pp. 13-28, Routledge, New York, NY.

Gamble, C., Gowlett, J. \& Dunbar, R., 2011, 'The social brain and the shape of the palaeolithic', Cambridge Archaeological Journal 21(1), 115-136. https://doi. palaeolithic', Cambridge Archaeo
org $10.1017 /$ S0959774311000072

Gould, S.J., 1977, Ontogeny and phylogeny, Harvard University Press, Cambridge, MA. Kitcher, P., 2011, The ethical project, Harvard University Press, Cambridge, MA.

Laland, K.N., Uller, T., Feldman, M.W., Sterelny, K., Muller, G.B., Moczek, A. et al., 2015 'The extended evolutionary synthesis: Its structure, assumptions and predictions', Proceedings of the Royal Society B: Biological Sciences 282, 20151019. https://doi org/10.1098/rspb.2015.1019

Ricoeur, P., 1992, Oneself as another, University of Chicago Press, Chicago, IL.

Serfontein, B., 2018, 'Imagination, religion, and morality: An interdisciplinary approach', PhD thesis, University of Pretoria, Pretoria.

Sober, E. \& Wilson, D.S., 1998, Unto others: The evolution and psychology of unselfish behavior, Harvard University Press, Cambridge, MA.

Tomasello, M., 1999, The cultural origins of human cognition, Harvard University Press, Cambridge, MA.

Tomasello, M., 2016, A natural history of human morality, Harvard University Press, Cambridge, MA.

Tomasello, M., 2019, Becoming human: A theory of ontogeny, Harvard University Press, Cambridge MA.

Tomasello, M. Melis, A., Tennie, C., Wyman, E. \& Herrmann, E., 2012, 'Two key steps in the evolution of human cooperation: The interdependence hypothesis', Current Anthropology 53(6), 673-692. https://doi.org/10.1086/668207

Van Huyssteen, J.W., 2006, Alone in the world: Human uniqueness in science and theology, Wm. B. Eerdmans, Grand Rapids, MI.

Van Huyssteen, J.W., 2010, 'Should we do what Jesus did? Evolutionary perspectives on Christology and ethics', in F.L. Shults \& B. Waters (ed.), Christology and ethics, pp. 149-178, Eerdmans, Grand Rapids, MI.

Van Huyssteen, J.W., 2016, 'Rethinking the theory of evolution: New perspectives on human evolution and why it matters for theology', HTS Teologiese Studies/ Theological Studies 72(4), a3664. https://doi.org/10.4102/hts.v72i4.3664

Van Huyssteen, J.W., 2017a, 'Lecture one: Rediscovering Darwin for theology Rethinking human personhood', HTS Teologiese Studies/Theological Studies 73(3), a4485. https://doi.org/10.4102/hts.v73i3.4485

Van Huyssteen, J.W., 2017b, 'Lecture two: The evolution of morality: The emergence of personhood', HTS Teologiese Studies/Theological Studies 73(3), a4487. https:// doi.org/10.4102/hts.v73i3.4487

Van Huyssteen, J.W., 2017c, 'Human origins and the emergence of a distinctively human imagination: Theology and the archaeology of personhood', in A. Fuentes \& A. Visala (eds.), Verbs, bones, and brains: Interdisciplinary perspectives on human nature, pp. 165-189, University of Notre Dame Press, Notre Dame, IN

Wake, D.B., Hadley, E.A. \& Ackerly, D.D., 2009, 'Biogeography, changing climates, and niche evolution', Proceedings of the National Academy of Science 106(2), 19631-19636. https://doi.org/10.1073/pnas.0911097106

West-Eberhard, M.J., 1979, 'Sexual selection, social competition, and evolution', Proceedings of the American Philosophical Society 51(4), 222-234.

West-Eberhard, M.J., 2003, Developmental plasticity and evolution, Oxford University Press, Oxford. 